\title{
CORRESPONDENCE
}

\author{
(To the Editors of the Journal of the Institute of Actuaries)
}

\section{Managed Monetary System and Full Employment}

\section{DEAR SIRS,}

On reading the contributions and discussions in the Fournal upon the above matters ( $\mathcal{F} . I . A$. Vol. LXXII, pp. 306 and 364 ), one is struck rather by what is left out than by what is included.

Stripped of all accessories, the prime subject involved is paper money.

Certain propositions are here suggested as almost axiomatic. They are:

(a) As a basis for long contracts such as those of life insurance and superannuation funds, the attribute of a 'store of value', not possessed by paper, and commonly overlooked in modern writings, is absolutely essential.

(b) Excursions by the State into the paper money sphere always do, and necessarily must, infect the currency with a downward force of gravity. (c) Any study of the psychology of the crowd reveals that Governments or States are mentally and emotionally as children (see Sir George Paish's apposite remark (loc. cit., p. 323) that Governments did not understand the rudiments of finance and were hopelessly ignorant). (d) Paper money does not create, but diverts, purchasing power. (e) Increase of paper money acts as a stimulant, but all stimulants are followed by depression. $(f)$ Life insurance and similar funds constitute a temptation to easy, insidiously deceptive, and plausible diversion of power by demagogues. $(g)$ The profession of actuary, concemed with long contracts, depends upon a stable currency. $(h)$ Over centuries and millennia, owing largely to its indestructibility and the inertia of its large existing mass, gold has been the most stable thing in the world. (i) Gold, unlike paper, and unlike almost any other possible or conceivable practical measure or store of value, is free from emotional impulses.

It is suggested that the proper basis of any discussion of managed currency and full employment is a consideration of the cause of crises.

In a paper contributed by me in 1931 to the Actuarial Society of Australasia upon the economic crisis, arguments were presented concerning the effects of paper money. It was shown that every war since the establishment of the Bank of England, save one, was followed by an immediate crisis and another about ten years later, the sole exception being the war of the Austrian Succession, concerning which an authority had said that there was little financial strain on Britain. It was also indicated that the South Sea Bubble, and the Mississippi debacle in France, were both due to war finance, involving paper money. Some years later (in 1939), Prof. Schumpeter of Harvard hesitatingly suggested the resemblance of the South Sea Bubble crisis to that of $x 929$.

I have for some considerable time past become convinced that the arguments and evidence contained in my I93 I paper can be epitomized in a clear and selfevident formula, which needs only to be enunciated to command at least some attention. That is to say, the most systematic and also the commonest cause of crises and unemployment is expressible in five simple words, namely paper money and Gresham's law, i.e. the law that bad money drives out good. These 
two simple elements should not be kept in separate compartments of the brain, as appears to be common. A search of numbers of authoritative essays upon the subject fails to find reference to Gresham's law in this connexion.

Bank notes are, of course, not the only kind of paper money; and even in the days of the gold standard, the bulk of the paper, though nominally and apparently. convertible, was really inconvertible, as was always evident when a certain amount of gold, by Gresham's law, left the country. Paper money had an unmoral origin, and is still infected with immorality. Over-issue, and'attempted defiance of Gresham's law, is of its very essence. The gilt coins of the Romans could not hold a candle to it, for unlike paper money they carried the evidence of their deceit and inferiority on their individual faces.

It should be obvious a priori that the linking together, on a basis of equality, of gold and paper, whereof the greater part was in fact inconvertible and therefore inferior as a currency, must have led to the periodical exit of gold as the sounder currency. From this point of view the periodical crises of last century were not only-inevitable but were the agents of a recovery, being thus a beneficial compcnsation for the paper money orgy and boom. The analogy to a drunken bout and subsequent recovery is surely delightful. Paper money is, in fact, the alcohol of nations; and it is suggested that a conscious realization that crises are the inevitable result of paper money should be death to some part of the more recent superstructure of modern economics. Those periodical booms and depressions were displayed before our eyes as a familiar spectacle during the whole of the nineteenth century, that great century of paper money: but our eyes were blind, and mostly still are, to the simple and elemental nature of the persistent struggle between paper money and Gresham's law and its inevitable results. Incidentally, many of the sins attributed to 'Capitalism' are really due to paper money.

Therefore actuaries (and who else?), in duty to the vast interests entrusted to their vigilance, should work earnestly for a sound currency to the exclusion of one 'managed' by the childlike crowd or Government, whose management we may be sure will never be devoted to the relatively or politically remote interests of our funds. The currency should be adequate to fulfil all its three functions, and not merely those two that satisfy day-to-day requirements only. This is not the least of our problems.

The discussions of the White Paper upon the remedy for unemployment mean in essence the issue of more paper to cure the results of too much paper: exactly analogous to prescribing more drink to the drunkard. Inconvertible paper money and crises are inseparable. Mitigation of crises lengthens, and postponement magnifies, them.

The attempt of Britain to return to the gold standard after the first world war was made in sheer defiance of Gresham's law, but unfortunately the blame for the failure was imputed to the gold standard, which, with all its defects, produced a sounder currency than wholly inconvertible paper ever did or ever will produce. Even at the present moment, in face of the ideal of a 'managed' currency we have the spectacle of the indulgence by Governments in wild paper money bouts precisely when strict sobriety is called for. Without the restraint imposed by convertibility into (say) gold, and the resultant periodical correction, paper money must, by the very principle of its being, tend to destroy itself. And it may be emphasized that the return to par after Waterloo was not due to Government action, but to the sharp discipline possible to a private concern serving the nation indirectly while moved by its own insistent individual interest: for strict 
responsibility is as much a characteristic of private banks for their paper as irresponsibility is a characteristic of the 'birds of passage' known as Governments.

I refrain from dilating upon the subject of the role played by pride in exaggerating the unemployment when it comes, and upon the effect of subsidizing that pride under the specious cry of 'full employment', and thereby damaging the interests under our care.

\section{Yours faithfully,}

A. T. TRAVERSI

43 Margaret Street

Sydney

Australia

I 6 fuly I947 